\title{
Microstructural characterization and microscopy analysis of laser cladding Stellite12 and tungsten carbide
}

\author{
K.A. Chiang, Y.C. Chen* \\ Laboratory of Surface Modification, Department of Mechanical Engineering, National Taiwan University, No. 1, Sec. 4, Roosevelt Road, Taipei 106, Taiwan
}

Received 15 April 2004; received in revised form 11 August 2006; accepted 14 August 2006

\begin{abstract}
Stellite12 cobalt base alloys with different WC content were deposited on SK3-carbon tool steel by laser cladding. The behavior of WC particulates, including the dissolution, distribution, and microstructures of $\mathrm{WC}-\mathrm{Co}-\mathrm{Cr}-\mathrm{C}$ composite coatings with rapidly solidifying were investigated using scanning electron microscopy (SEM), electron probe microanalysis (EPMA) and X-ray diffraction (XRD). Several significantly different solidified microstructures were characterized by dendrites, interdendritic eutectics, faceted dendrites (third phase) and the retaining of WC particles in the laser clads of Stellite12 + WC, under different laser energy densities. When WC was completely melted and fully dissolved into the Stellite12 melt pool, the basic solidification, characterized by the matrix and faceted dendrites (third phase) in various shapes, and the compositional evolution of the clad layers remained nearly identical, no matter the added WC was increased to $10 \%, 20 \%$ or $40 \%$ (wt. $\%$ ). The faceted dendrites (third phase) contained the majority of $\mathrm{W}$ as well as some $\mathrm{Cr}$, Co while more $\mathrm{Cr}$ and Co were located in the matrix. The X-ray diffraction analyses indicated the existence of $\sigma-\mathrm{Co}, \mathrm{M}_{23} \mathrm{C}_{6}, \mathrm{M}_{6} \mathrm{C}$ and $\mathrm{M}_{7} \mathrm{C}_{3}(\mathrm{M}=\mathrm{W}, \mathrm{Cr}, \mathrm{Co})$ in the Stellite12 alloys with different WC contents when deposited on substrates by laser cladding.
\end{abstract}

(C) 2006 Elsevier B.V. All rights reserved.

Keywords: Stellite12; WC; Laser cladding

\section{Introduction}

Industrial applications of laser surface modification are popular due to the advantages of high power density, thin hardening layer, lower heat input and a less heat-affected zone. This is especially true in the application of laser surface cladding for high-technology products. Recently, much attention has been focused on the study of surface cladding of alloys, cements and ceramics. In this process the laser surface melting, followed by rapid self-cooling of the melted layer, can produce very refined microstructures with unusual properties, directly on the surface of the work piece [1-4].

In this paper, cobalt-based alloy (Stellite12) and $\mathrm{WC}-\mathrm{Co}-$ $\mathrm{Cr}-\mathrm{C}$ composite coatings, produced under different laser energy densities were characterized by scanning electron microscopy (SEM) in order to determine their microstructure evolution. In addition, the behavior of WC particulates, including the dissolution, distribution, and effects of WC + Stellite 12 coatings with rapidly solidified microstructure was investigated.

\footnotetext{
* Corresponding author. Fax: +88622362 5489.

E-mail address: d89522007@ ntu.edu.tw (Y.C. Chen).
}

\section{Experimental procedures}

Mixtures of Stellite12 alloy powder and 10, 15, 20, 30 and $40 \mathrm{wt} . \%$ WC powders, respectively, were used as the coating material. The particles of the Co-base alloy powders were from 5 to $10 \mu \mathrm{m}$ in size. The nominal composition of the Stellite12 alloy powder is listed in Table 1. The particles of the WC powders measured from 5 to $10 \mu \mathrm{m}$ in size. The high carbon tool steel SK3 (with $\mathrm{C}>1.0 \%$ ) specimen was machined into a rectangular block with a slot, as shown in Fig. 1. Mixtures of Stellite12 alloy powder and WC powders were positioned on the slot and then cladded by laser treatment.

The laser treatment was performed using a $2.5 \mathrm{~kW}$ continuous wave $\mathrm{CO}_{2}$ laser. A $\mathrm{Zn}-\mathrm{Se}$ lens, with a $7.5 \mathrm{in}$. focal length was used to focus the beam. The laser energy density used in the experiments was in the range $22.92-106.95 \mathrm{~J} / \mathrm{mm}^{2}$, with a $1 \mathrm{~mm}$ beam diameter. In order to produce oxide free coatings in all experiments, the laser was shielded with $\mathrm{N}_{2}$ gas. Cross-sections of the layers were examined for microstructure and the distribution of hard phases by SEM. The composition of the layers were measured by energy dispersive $\mathrm{X}$-ray (EDX) microanalysis and characterized by X-ray diffraction (XRD).

\section{Results and discussions}

Fig. 2(a)-(c) shows the cross-section of the laser clad Stellite12 alloy layers under $38.2,57.3,66.8 \mathrm{~J} / \mathrm{mm}^{2}$ laser energy density, respectively. The typical microstructure of the Stellite 12 alloy (as shown in Fig. 2), consists of $\alpha$-Co (Co-rich matrix) 
Table 1

Nominal composition (wt.\%) of Co-base alloys Stellite12

\begin{tabular}{ll}
\hline Stellite12 & \\
$\mathrm{Co}$ & Balance \\
$\mathrm{Cr}$ & 29 \\
$\mathrm{C}$ & 1.85 \\
$\mathrm{~W}$ & 9 \\
$\mathrm{Mo}$ & - \\
$\mathrm{Ni}$ & 2.5 \\
$\mathrm{Si}$ & 1 \\
$\mathrm{~B}$ & - \\
$\mathrm{Fe}$ & 2.5 \\
$\mathrm{Mn}$ & 1
\end{tabular}

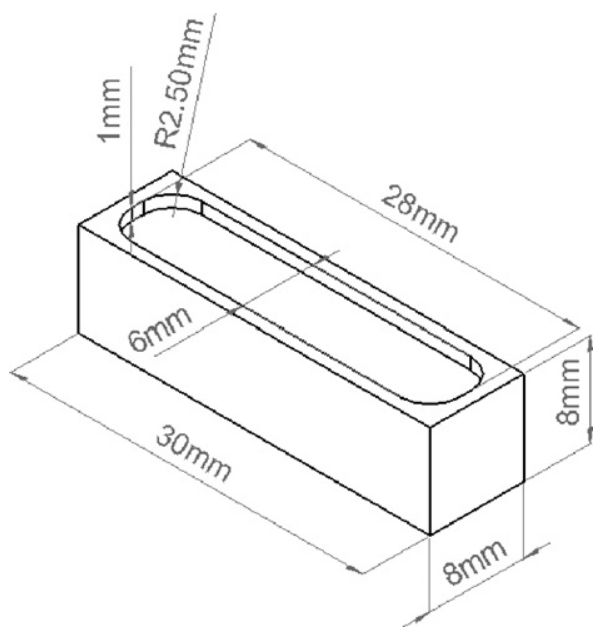

Fig. 1. Dimension of specimen machined into rectangular and slotted bar.

dendrites with a face-centered cubic (fcc) crystal structure surrounded by a lamellar mixture of the Co-rich phase and carbide phase resulting from the eutectic reaction into inter-dendrite during solidification [5-7]. The compositional evolution in the dendrites and inter-dendrite eutectics of Fig. 2, by EDX analysis, are listed in Table 2. Table 2 indicates that the elements $\mathrm{Co}, \mathrm{Cr}, \mathrm{W}$ of the dendrites and the eutectics decreased with the increase in laser energy density. At the same time, the dilution of the element Fe increased rapidly when the laser energy density increased. In Stellite 12 alloys, $\mathrm{Cr}$ provides oxidation and corrosion resistance as well as strength through the formation of $\mathrm{M}_{7} \mathrm{C}_{3}$ and $\mathrm{M}_{23} \mathrm{C}_{6}$ carbides $(\mathrm{M}=\mathrm{Co}, \mathrm{Cr}, \mathrm{W})$. Refractory metal such as $\mathrm{W}$, which has been known to be a solid-solution hardening element, also contributes to the strength via precipitation hardening by the formation of $\mathrm{MC}$ and $\mathrm{M}_{6} \mathrm{C}$ carbides, and through the inter-metallic phase such as $\mathrm{Co}_{3} \mathrm{~W}$. In addition, $\mathrm{C}$ and $\mathrm{Fe}$ promote the stability
Table 2

Compositional evolution in the dendrites and the interdendritic eutectics of Fig. 2

\begin{tabular}{cllccr}
\hline $\begin{array}{l}\text { Laser energy } \\
\text { density }\end{array}$ & $\begin{array}{l}\text { Co } \\
(\text { wt.\%) }\end{array}$ & $\begin{array}{l}\text { Cr } \\
(\text { wt.\%) }\end{array}$ & W (wt.\%) & C (wt.\%) & $\begin{array}{l}\text { Fe } \\
\text { (wt.\%) }\end{array}$ \\
\hline $\begin{array}{c}38.2 \mathrm{~J} / \mathrm{mm}^{2} \\
\text { Dendrite }\end{array}$ & 52.12 & 24.94 & 9.43 & 2.7 & 10.81 \\
Eutectic & 24.79 & 37.95 & 22.27 & 9.11 & 5.88 \\
$57.3 \mathrm{~J} / \mathrm{mm}^{2}$ & & & & & \\
Dendrite & 38.68 & 17.52 & 8.7 & 2.21 & 32.89 \\
Eutectic & 14.01 & 35.58 & 18.39 & 10.19 & 21.84 \\
$66.8 \mathrm{~J} / \mathrm{mm}^{2}$ & & & & & \\
Dendrite & 31.36 & 14.23 & 8.06 & 3.78 & 42.57 \\
Eutectic & 25.54 & 19.09 & 9.7 & 6.36 & 39.32 \\
\hline
\end{tabular}

of an fcc structure of a Co-rich matrix, which is stable at high temperatures up to its melting point of $1495^{\circ} \mathrm{C}[8,9]$.

When WC (10 wt.\%) was added into the Stellite12 powder under $28.65,38.20,45.84,50.93 \mathrm{~J} / \mathrm{mm}^{2}$ laser energy density, respectively, several significantly different solidification characteristics were found in the microstructure evolution in the laser clads of Stellite12+WC. Fig. 3 demonstrates the solidification characteristic of the microstructure evolution as the laser energy density increases. All the SEM microstructure images were taken in the middle part of the laser clad layers. The first image was characterized by dendrites and inter-dendrite eutectics and retained WC particles, as shown in Fig. 3(a). The second one was characterized by dendrites and inter-dendrite eutectics, retained WC particles and third phases, as shown in Fig. 3(b). The third one was characterized by retained WC particles, third phases (faceted dendrites) in various shapes, dendrites and inter-dendrite eutectics, as shown in Fig. 3(c). The last one was characterized by retained $\mathrm{WC}$ particles, third phases and the matrix as shown in Fig. 3(d).

In Fig. 3(a), when the laser moves away, the molten Stellite12 starts to solidify. According to the $\mathrm{Co}-\mathrm{Cr}-\mathrm{W}$ phase diagram, a Co-rich phase is then first formed dendritically from the liquid state. The cooling rate in the liquid state is very high through selfcooling, and $\mathrm{Cr}$ and $\mathrm{C}$ become enriched in the remaining liquid in the inter-dendrite regions, and a eutectic carbide structure forms. The WC particles did not completely melt and dissolve into the Stellite12 melt pool. When the laser energy density was raised, it becomes evident from Fig. 3(b)-(d), that the microstructure, characterized by the matrix and faceted dendrites (third phases) in various shapes and the eutectics became dissolved in the clad layer $[10,11]$. The added WC particles are normally melted and dissolved into the Stellite12 melt pool. However, some

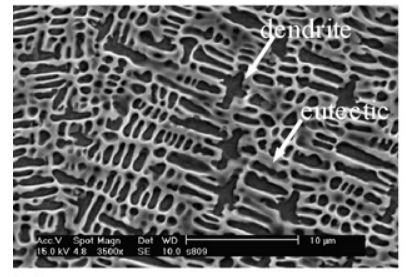

(a)

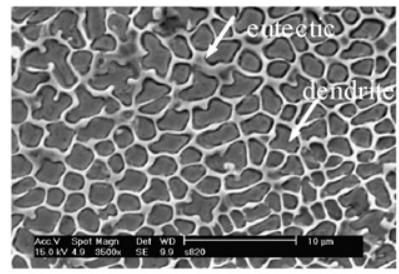

(b)

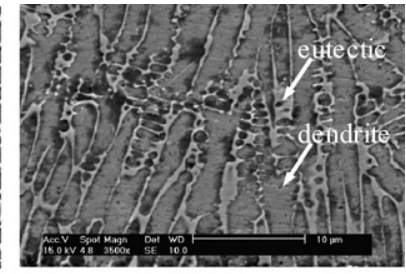

(c)

Fig. 2. SEM micrograph showing the microstructure of the laser clad Stellite12 alloy coating (a) $38.2 \mathrm{~J} / \mathrm{mm}^{2}$, (b) $57.3 \mathrm{~J} / \mathrm{mm}^{2}$, and (c) $66.8 \mathrm{~J} / \mathrm{mm}^{2}$. 


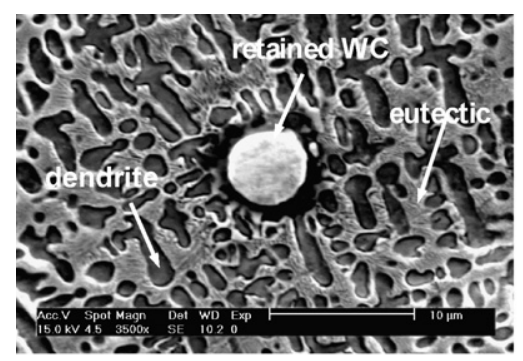

(a)

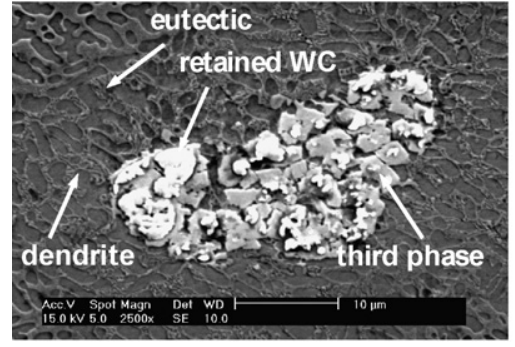

(c)

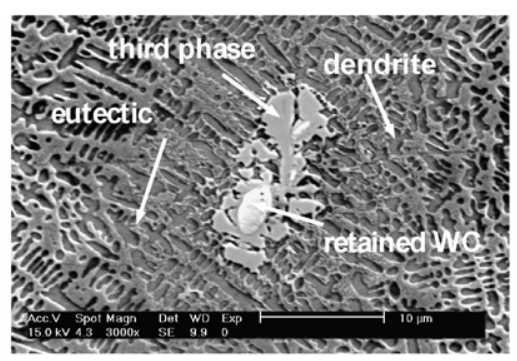

(b)

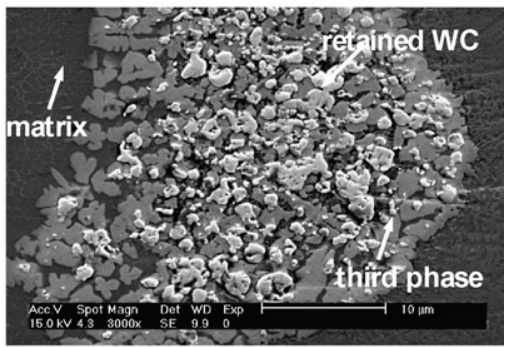

(d)

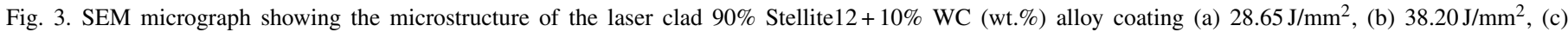
$45.84 \mathrm{~J} / \mathrm{mm}^{2}$, and (d) $50.93 \mathrm{~J} / \mathrm{mm}^{2}$.

un-melted WC particles were observed by SEM, as shown in Fig. 3(b) and (c). When the laser energy density was raised, the extent of the melting of the substrate increased and the clad layers became substantially diluted by $\mathrm{Fe}$, which caused the change of composition and microstructure [12,13]. The compositional evolution of $\mathrm{Co}, \mathrm{Cr}, \mathrm{W}, \mathrm{C}$ and $\mathrm{Fe}$ in different solidification characteristics of Fig. 3, as determined by EDX analysis, is listed in Table 3. It is evident from Table 3 that when the laser energy density was raised from 28.65 to $45.84 \mathrm{~J} / \mathrm{mm}^{2}$, the compositional evolution of $\mathrm{Cr}, \mathrm{W}$ and $\mathrm{C}$ in eutectics decreased gradually. At the same time the compositional evolution of Co in eutectics

Table 3

Compositional evolution in the retained WC, third phases, dendrites, interdendritic eutectics and the matrix of Fig. 3

\begin{tabular}{|c|c|c|c|c|c|}
\hline $\begin{array}{l}\text { Laser energy } \\
\text { density }\end{array}$ & $\begin{array}{l}\text { Co } \\
\text { (wt.\%) }\end{array}$ & $\begin{array}{l}\mathrm{Cr} \\
\text { (wt.\%) }\end{array}$ & W (wt.\%) & $\mathrm{C}$ (wt.\%) & $\begin{array}{l}\mathrm{Fe} \\
\text { (wt.\%) }\end{array}$ \\
\hline \multicolumn{6}{|l|}{$28.65 \mathrm{~J} / \mathrm{mm}^{2}$} \\
\hline Retained WC & 0 & 0 & 93.09 & 6.91 & 0 \\
\hline Dendrite & 60.89 & 21.46 & 12.87 & 0 & 4.79 \\
\hline Eutectic & 26.60 & 35.6 & 29.47 & 5.50 & 2.83 \\
\hline \multicolumn{6}{|l|}{$38.20 \mathrm{~J} / \mathrm{mm}^{2}$} \\
\hline Retained WC & 0 & 0 & 96.87 & 3.13 & 0 \\
\hline Third phase & 21.16 & 13.76 & 61.54 & 2.36 & 1.18 \\
\hline Dendrite & 52.83 & 27.84 & 14.45 & 0 & 4.88 \\
\hline Eutectic & 33.98 & 31.68 & 27.14 & 5.2 & 2.00 \\
\hline \multicolumn{6}{|l|}{$45.84 \mathrm{~J} / \mathrm{mm}^{2}$} \\
\hline Retained WC & 0 & 0 & 91.6 & 8.4 & 0 \\
\hline Third phase & 16.69 & 8.67 & 70.13 & 4.52 & 0 \\
\hline Dendrite & 48.82 & 30.64 & 15.54 & 0 & 5 \\
\hline Eutectic & 36.14 & 30.83 & 25.07 & 4.63 & 3.33 \\
\hline \multicolumn{6}{|l|}{$50.93 \mathrm{~J} / \mathrm{mm}^{2}$} \\
\hline Retained WC & 0 & 0 & 95.84 & 4.16 & 0 \\
\hline Third phase & 17.38 & 8.02 & 71.68 & 2.08 & 0.85 \\
\hline Matrix & 20.52 & 31.9 & 14.61 & 4.25 & 28.72 \\
\hline
\end{tabular}

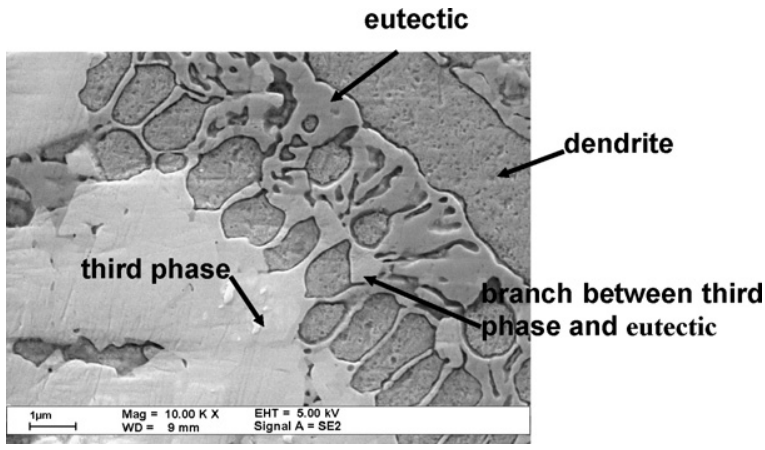

Fig. 4. SEM micrograph showing the microstructure of the laser clad $90 \%$ Stellite $12+10 \% \mathrm{WC}$ (wt.\%) alloy coating under $38.20 \mathrm{~J} / \mathrm{mm}^{2}$ laser energy density.

increased. EDX analysis indicates that this third phase structure has less $\mathrm{Co}, \mathrm{Cr}$ and $\mathrm{C}$ compared to the eutectic, and that its main characteristic was that it had more than 60 (wt.\%) W, which is substantially more than the $\mathrm{W}$ content in either the eutectic matrix itself or the dendrites.

Fig. 4 shows that, when carefully observed, it is evident that this third phase appears in the eutectic carbides. EDX analysis, as shown in Table 4, indicates that the compositional evolution of $\mathrm{Co}, \mathrm{Cr}$, and $\mathrm{C}$ in eutectic carbides seems to diffuse into the

Table 4

Compositional evolution in the dendrites and the interdendritic eutectics of Fig. 4

\begin{tabular}{lllll}
\hline Laser energy density & $\begin{array}{l}\text { Co } \\
(\mathrm{wt} \%)\end{array}$ & $\begin{array}{l}\mathrm{Cr} \\
(\mathrm{wt} . \%)\end{array}$ & $\mathrm{W}$ (wt.\%) & $\mathrm{C}$ (wt.\%) \\
\hline $\begin{array}{lllll}38.20 \mathrm{~J} / \mathrm{mm}^{2} \\
\text { Third phase }\end{array}$ & 13.25 & 5.94 & 65.56 & 15.25 \\
$\begin{array}{l}\text { Branch between third } \\
\quad \text { phase and eutectic }\end{array}$ & 21.61 & 19.48 & 43.48 & 15.43 \\
$\quad$ & & & \\
$\quad \begin{array}{l}\text { Eutectic } \\
\text { Dendrite }\end{array}$ & 27.88 & 32.98 & 18.97 & 20.16 \\
\hline
\end{tabular}




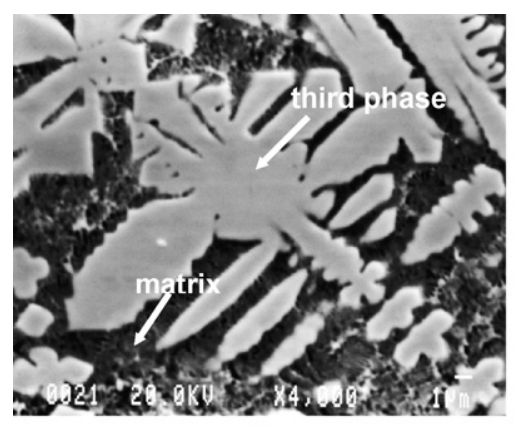

(a)

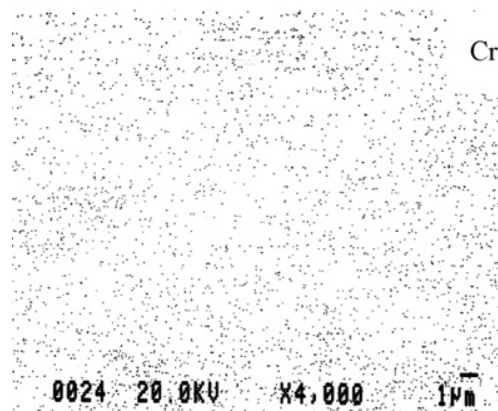

(c)

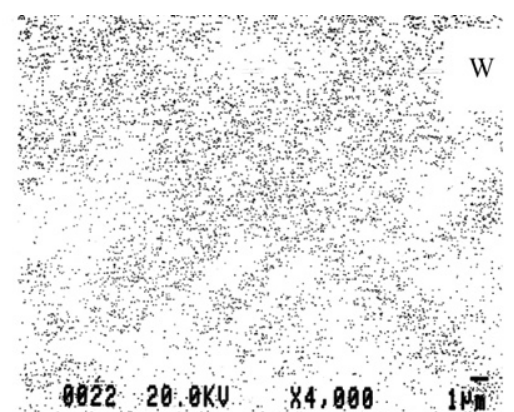

(b)

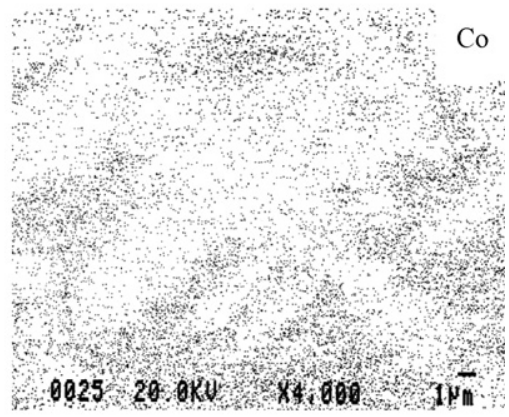

(d)

Fig. 5. Backscattered electron images and elemental mapping of cross-section of the $10 \% \mathrm{WC}+90 \%$ Stellite 12 alloys coating under $50.93 \mathrm{~J} / \mathrm{mm}^{2}$ laser energy density: (a) backscattered electron image, (b) W element distribution, (c) Cr element distribution, and (d) Co element distribution.

third phase. It was noted earlier that the basic microstructure of the laser clad of Stellite12 is a primary cubic $\alpha$-Co (Co-rich matrix) dendrites with a face-centered cubic (fcc) crystal structure, surrounded by a lamellar mixture of the Co-rich phase and the carbide phase like $\mathrm{M}_{7} \mathrm{C}_{3}$, resulting from the eutectic reaction into inter-dendrite during solidification. The solubility of some alloying elements like $\mathrm{W}$ will extend into the cubic $\alpha$-Co dendrites, and most of the $\mathrm{W}$ will be contained in the eutectics.

However, when more $\mathrm{W}$ enters into the melt, neither the eutectic nor the dendrite will be able to contain that large an amount of $\mathrm{W}$, and consequently the remaining $\mathrm{W}$ may presumably solidify into a third phase structure in some other form of

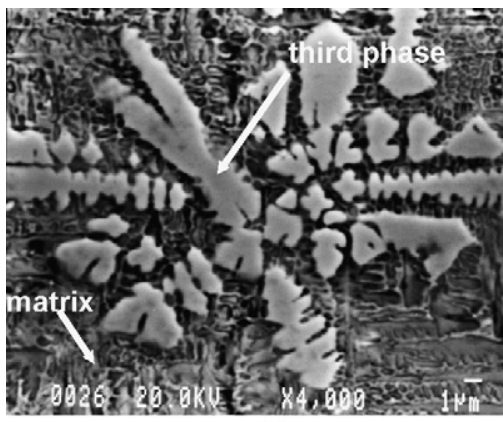

(a)

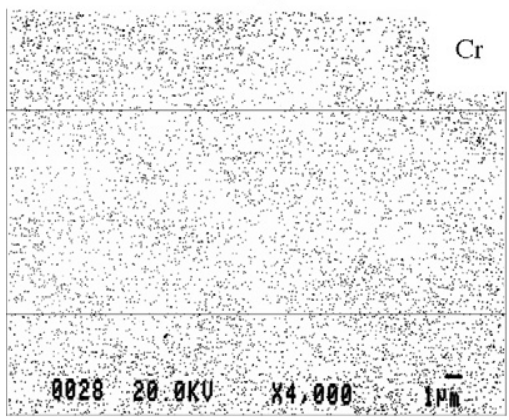

(c)

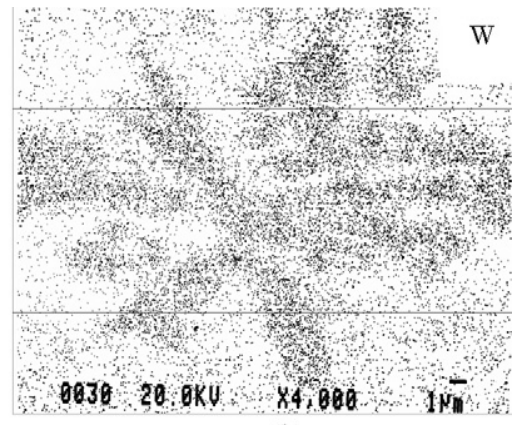

(b)

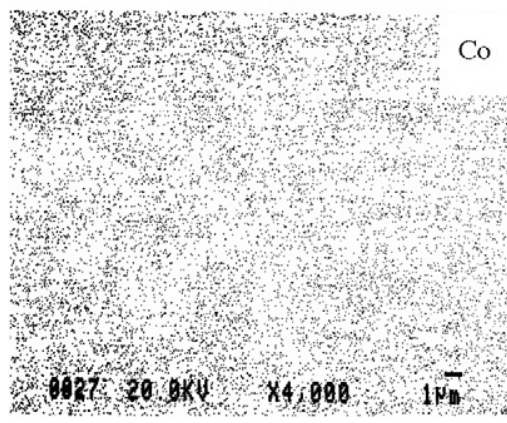

(d)

Fig. 6. Backscattered electron images and elemental mapping of cross-section of the $20 \% \mathrm{WC}+80 \%$ Stellite 12 alloys coating under $50.93 \mathrm{~J} / \mathrm{mm}^{2}$ laser energy density: (a) backscattered electron image, (b) W element distribution, (c) Cr element distribution, and (d) Co element distribution. 


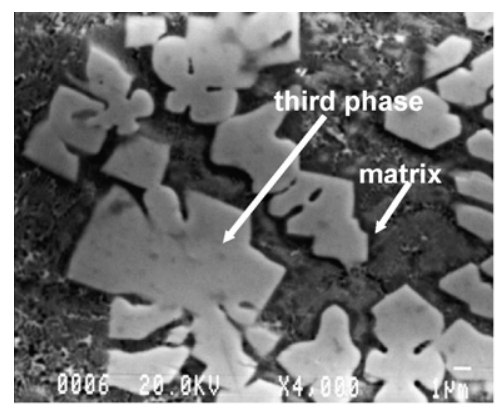

(a)

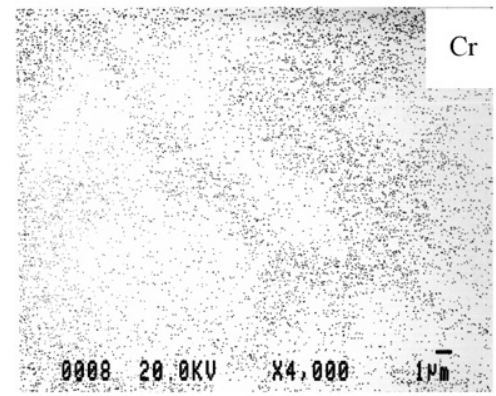

(c)

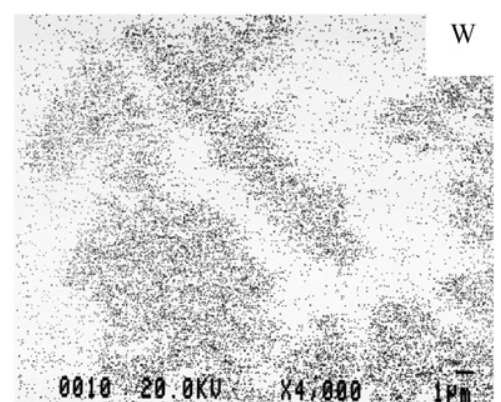

(b)

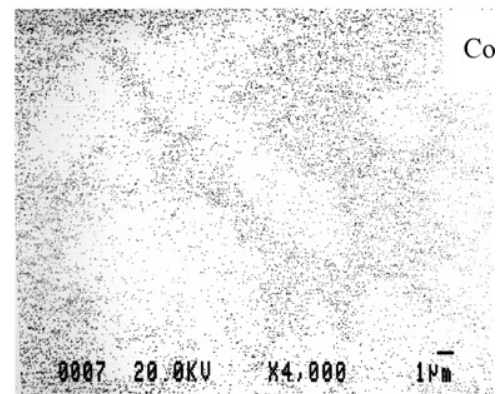

(d)

Fig. 7. Backscattered electron images and elemental mapping of cross-section of the $40 \% \mathrm{WC}+60 \%$ Stellite 12 alloys coating under $50.93 \mathrm{~J} / \mathrm{mm}^{2}$ laser energy density: (a) backscattered electron image, (b) W element distribution, (c) Cr element distribution, and (d) Co element distribution.

tungsten carbides which contain more W. Since most of the W is contained in the eutectics, the redundant $\mathrm{W}$ can only solidify in the eutectic area [14].

Backscattered electron images and elemental mapping of cross-sections of the $10 \%, 20 \%, 40 \% \mathrm{WC}+$ Stellite 12 alloys coating under $50.93 \mathrm{~J} / \mathrm{mm}^{2}$ laser energy density are shown in Figs. 5-7. From Figs. 5(a)-7(a), it is evident that the added WC is completely melted and fully dissolved into the Stellite 12 melt pool, and the basic solidification characterized by the matrix and faceted dendrites (third phases) in various shapes of the clad layers were maintained in almost identical form. The element mapping of W, Cr, Co of the 10\%, 20\%, 40\% WC+Stellite12 alloys coating are shown in Figs. 5(b)-(d), 6(b)-(d) and 7(b)-(d), respectively, and exhibit the distribution of the main elements $\mathrm{W}, \mathrm{Cr}$, Co in both the third phases and the matrix. It indicates that with the increase of WC in the Stellite 12 powder, the faceted dendrites (third phases) contain a majority of $\mathrm{W}$ as well as some $\mathrm{Cr}$, and $\mathrm{Co}$, while the matrix contains more $\mathrm{Cr}$ and $\mathrm{Co}$. It is worth noting that the distribution of $\mathrm{W}$ becomes noticeably concentrated in the third phases, while $\mathrm{Cr}$ and Co were mostly located in the matrix as shown in Fig. 7(b)-(d). In Table 5, when the added WC was increased to $10 \%, 20 \%$ and $40 \%$, respectively, it was evident that the compositional evolution of $\mathrm{Cr}, \mathrm{W}$ and $\mathrm{C}$ in third phases was almost identical. Most of the $\mathrm{W}$ was in the faceted dendrites (third faces) containing more than $60 \mathrm{wt} . \%$ when the added WC was increased to $10 \%, 20 \%$ and $40 \%$, respectively. It was also evident that due to the melting of the substrate and the dilution of the clad layers, the matrix contained more and more Fe.

X-ray diffraction analyses (Fig. 8) indicated the existence of $\sigma$-Co (Co-rich matrix phase), $\mathrm{M}_{23} \mathrm{C}_{6}$ type carbides with an fcc crystal structure, $\mathrm{M}_{6} \mathrm{C}$ and $\mathrm{M}_{7} \mathrm{C}_{3}$ with an orthorhombic crystal

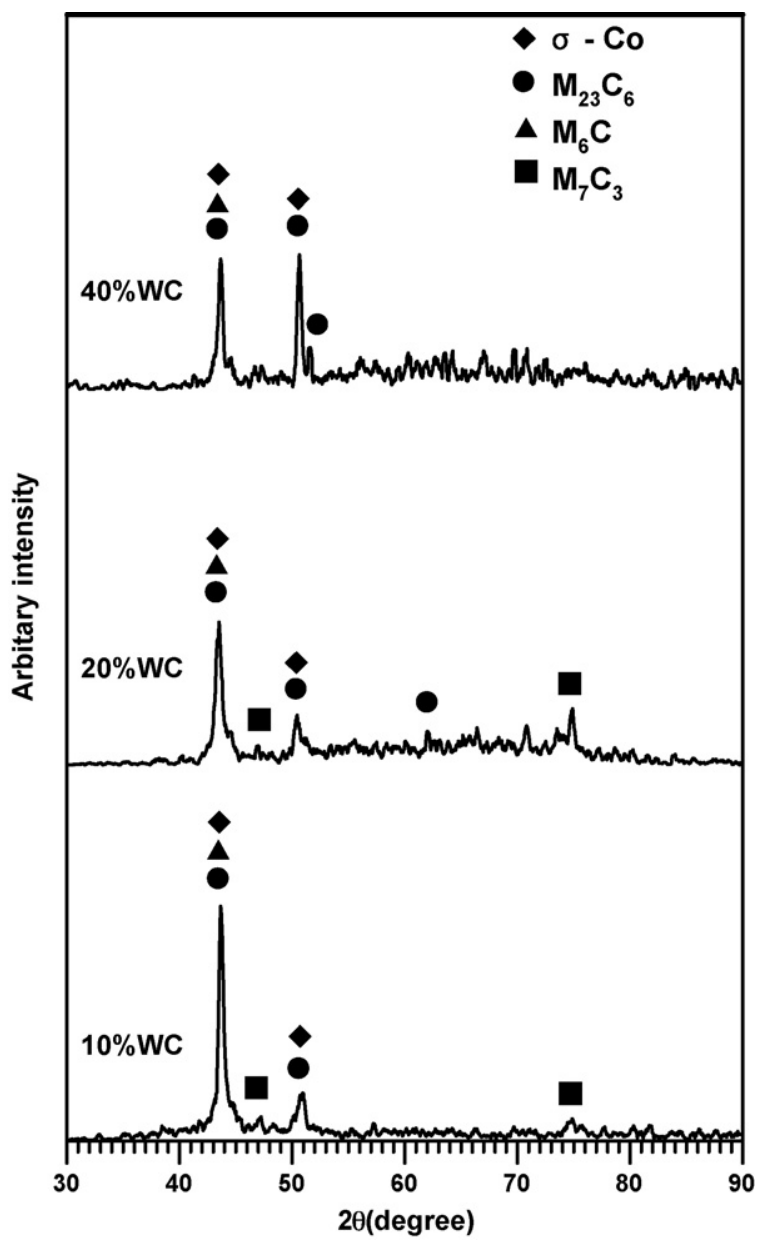

Fig. 8. X-ray diffraction result of the laser clad Stellite $12+10 \%, 20 \%, 40 \%$ WC. 
Table 5

Compositional evolution in the third phases and the matrix of the WC + Stellite12 alloys coating under $45.84 \mathrm{~J} / \mathrm{mm}^{2}$ laser energy density

\begin{tabular}{|c|c|c|c|c|c|}
\hline Contents & $\begin{array}{l}\mathrm{Co} \\
\text { (wt.\%) }\end{array}$ & $\begin{array}{l}\mathrm{Cr} \\
\text { (wt.\%) }\end{array}$ & W (wt.\%) & $\mathrm{C}(\mathrm{wt} . \%)$ & $\begin{array}{l}\mathrm{Fe} \\
(\mathrm{wt} . \%)\end{array}$ \\
\hline \multicolumn{6}{|c|}{$10 \% \mathrm{WC}+90 \%$ Stellite 12} \\
\hline Third phase & 16.21 & 11.0 & 67.71 & 2.21 & 2.87 \\
\hline Matrix & 45.95 & 25.38 & 19.20 & 4.74 & 4.73 \\
\hline \multicolumn{6}{|c|}{$20 \%$ WC $+80 \%$ Stellite 12} \\
\hline Third phase & 18.7 & 12.89 & 63.72 & 2.39 & 2.3 \\
\hline Matrix & 46.92 & 26.49 & 18.21 & 3.56 & 4.82 \\
\hline \multicolumn{6}{|c|}{$40 \% \mathrm{WC}+60 \%$ Stellite 12} \\
\hline Third phase & 18.14 & 10.04 & 66.54 & 2.14 & 3.14 \\
\hline Matrix & 44.65 & 25.93 & 17.79 & 1.78 & 9.85 \\
\hline
\end{tabular}

structure $(\mathrm{M}=\mathrm{W}, \mathrm{Cr}, \mathrm{Co})$ in the $10 \%$ and $20 \% \mathrm{WC}+$ Stellite 12 alloys coating under $50.93 \mathrm{~J} / \mathrm{mm}^{2}$ laser energy density [15]. It is not easy to identify the carbides though a simple comparison of XRD peaks and JCPDS values because of the wide range of solubility limits of most carbides. When comparing the $10 \%$ and $20 \%$ $\mathrm{WC}+$ Stellite12 alloy coatings, it was noticed that the carbides transform from $\mathrm{M}_{7} \mathrm{C}_{3}$ to $\mathrm{M}_{23} \mathrm{C}_{6}$ in the $40 \% \mathrm{WC}+$ Stellite 12 alloy coating.

\section{Conclusions}

Several significantly different solidification characteristics were found in the laser clads of Stellite $12+$ WC. When increasing the laser energy density in the solidification characteristic, the first clad layer was characterized by dendrites and interdendritic eutectics and retained WC particles, the second one was characterized by dendrites and interdendritic eutectics, retained WC particles and third phases (faceted dendrites) which were appeared in the eutectic carbides, the third one was characterized by retained WC particles, third phases in various shapes, dendrites and interdendritic eutectics and the last one was characterized by retained WC particles, third phases and the matrix. When WC was completely melted and fully dissolved into the Stellite 12 melt pool, the basic solidification, characterized by the matrix and faceted dendrites (third phases) in various shapes, and the compositional evolution of the clad layers were maintained nearly identical. The faceted dendrites (third phases) contained the majority of $\mathrm{W}$ as well as some $\mathrm{Cr}$ and $\mathrm{Co}$, while there was more $\mathrm{Cr}$ and $\mathrm{Co}$ located in the matrix. The $\mathrm{X}$-ray diffraction analyses indicated the existence of $\sigma-\mathrm{Co}, \mathrm{M}_{23} \mathrm{C}_{6}, \mathrm{M}_{6} \mathrm{C}$ and $\mathrm{M}_{7} \mathrm{C}_{3}$ $(\mathrm{M}=\mathrm{W}, \mathrm{Cr}, \mathrm{Co})$ in the $10 \%$ and $20 \% \mathrm{WC}+$ Stellite 12 alloy coatings. It was noticed that the carbides transformed from $\mathrm{M}_{7} \mathrm{C}_{3}$ to $\mathrm{M}_{23} \mathrm{C}_{6}$ when $40 \mathrm{wt} . \% \mathrm{WC}$ was added into the Stellite 12 powder.

\section{References}

[1] J. Singh, J. Mazumder, Mater. Sci. Technol. 2 (1986) 709.

[2] J. Singh, J. Mazumder, Metall. Mater. Trans. A 18 (1987) 313-322.

[3] J. Powell, P.S. Henry, W.M. Steen, Surf. Eng. 4 (1988) 141-149.

[4] K.C. Atony, A.N. Antony, K.J. Bhansali, Hardfacing, vol. 6, ASM Handbook, 1983, pp. 771-773.

[5] K. Nagarathnam, K. Komvopoulos, Metall. Mater. Trans. A 26 (1995) 2131-2139.

[6] N. Pizurova, J. Komurka, et al., Mater. Sci. Technol. 9 (1993) 172-175.

[7] A. Frenk, W. Kurz, Mater. Sci. Eng. A 173 (1993) 339-342.

[8] K.C. Atony, JOM 39 (1983) 52.

[9] J.C. Shin, J.M. Doh, J.K. Yoon, D.Y. Lee, J.S. Kim, Surf. Coat. Technol. 166 (2003) 117-126.

[10] R.C. Gassmann, Mater. Sci. Technol. 12 (1996) 691-696.

[11] R. Villar, J. Laser. Appl. 11 (1990) 64-79.

[12] M.R. Fishman, E. Rabkin, Mater. Sci. Eng. A 302 (2001) 106-109.

[13] Y. Yang, H.C. Man, Surf. Coat. Technol. 132 (2000) 130-133.

[14] M. Zhong, W. Liu, et al., Surf. Coat. Technol. 157 (2002) 128-137.

[15] P. Wu, C.Z. Zhou, et al., Surf. Coat. Technol. 73 (1995) 111-114. 